\title{
PENGARUH RASIO KEUANGAN TERHADAP PERUBAHAN RETURN SAHAM PADA PERUSAHAAN PERKEBUNAN YANG TERDAFTAR DI BURSA EFEK INDONESIA
}

\author{
Yogi Agung Prasetyo \\ Yogiiagung97@gmail.com \\ Universitas Ahmad Dahlan \\ Desta Rizky Kusuma \\ kusuma.desta@gmail.com \\ Universitas Ahmad Dahlan
}

\begin{abstract}
ABSTRAK
This study aimed to examine the effect of financial ratios on changes in stock returns in 2010-2014. Objects of this study are plantation company listed on the Indonesia Stock Exchange. The sampling technique used purposive sampling method while data analyst method used multiple linear regression. The results showed that the variable of Total Asset Turnover (TAT) and Return On Assets (ROA) has positive effect on changes in stock return, while variable Current Ratio (CR), Debt to Equity Ratio (DER) and Price Earning Ratio (PER) has no effect on retun stock.
\end{abstract}

Keywords: Financial Ratio; CR; DER; TAT; ROA; PER; Stock Returns.

\section{PENDAHULUAN}

Setiap investor yang melakukan investasi tentu mengharapkan keuntungan di masa yang akan datang. Investasi pada dasarnya tentu untuk menghasilkan keuntungan tetapi disisi lain juga bisa mengalami kerugian dari investasi terebut. Hal tersebut yang harus diperhatikan oleh investor supaya mereka mendapat keuntungan bukan kerugian dari investasi yang dilakukannya. Selain kehati-hatian dalam memiih investasi, investor juga harus berani menanggung resiko, semakin besar keuntungan maka semakin besar juga peluang untuk mengalami kerugian. Pada investasi harapan keuntungan disebut dengan return. Return (kembalian) adalah tingkat keuntungan yang dinikmati oleh pemodal atas suatu investasi yang dilakukannya (Ang, 1997).

Para investor dalam melakukan investasi di pasar modal. Pasar modal Indonesia, yaitu Bursa Efek Indonesia (BEI) dapat menjadi media pertemuan antara investor dan industri yang menjual sahamnya ke publik. Pasar modal dalam aktivitasnya menjalankan fungsi ekonomi dan keuangan. Pada fungsi ekonomi inilah pasar modal menyediakan fasilitas untuk pemindahan dana dari yang kelebihan dana (lender) ke pihak yang membutuhkan dana (borrower). Kegiatan aktivitas tersebut berbeda dengan yang ada pada perbankan. Perbedaannya kalau di pasar modal memperdagangkan dana dan lebih bersifat jangka panjang dan juga dilakukan secara langsung tanpa perantara lembaga keuangan.

Sebelum melakukan investasi, para calon investor tentunya memerlukan informasi yag berkaitan dengan pelaksanaan investasinya. Informasi yang diperlukan oleh para investor di pasar modal tidak hanya informasi yang bersifat fundamental saja, tetapi juga informasi yang bersifat teknikal. Informasi yang bersifat fundamental diperoleh dari kondisi internal perusahaan dan informasi yang bersifat teknikal diperoleh dari luar 
perusahaan seperti ekonomi, politik, finansial, dan faktor lainnya. Informasi yang dari kondisi internal perusahaan yang lazim digunakan adalah informasi laporan keuangan. Informasi fundamental dan teknikal tersebut dapat digunakan sebagai dasar bagi investor untuk memprediksi return, resiko atau ketidak pastian, jumlah, waktu, dan faktor lain yang berhubungan dengan aktivitas di pasar modal.

Para investor sebelum melakukan investasi harus lebih cermat dan teliti dalam menetukan pilihannya. Keuntungan yang diharapkan akan tercapai dan resikonya akan diminimalisasikan. Para investor untuk mencari informasi tentang perusahaan bisa menggunakan informasi fundamental yang lazim digunakan adalah informasi laporan keuangan. Laporan keuangan adalah sebuah informasi yang penting bagi investor dalam mengambil keputusan investasi. Laporan keuangan yang disajikan dalam manajemen perusahaan yang lazim digunakan dalam memprediksi saham meliputi neraca, laporan laba rugi, laporan perubahan modal dan laporan arus kas. Hal ini tidak relevan jika tidak menggunakan analisis rasio keuangan yang biasanya menjadi alat ukur perusahaan untuk mengetahui apakah kinerja keuangan yang selama periode berjalan menguntungkan bagi perusahaan dalam pasar modal atau malah merugikan perusahaan. Manfaat laporan keuangan tersebut menjadi optimal bagi investor apabila investor dapat menganalisis lebih lanjut melalui analisis rasio keuangan (Penman, 1991). Horigan (1965) bahwa rasio keuangan berguna untuk memprediksi kesulitan keuangan perusahaan, hasil operasi, kondisi keuangan perusahaan saat ini dan pada masa mendatang, serta sebagai pedoman bagi investor mengenai kinerja masa lalu dan masa mendatang. Rasio keuangan mempunyai beberapa rasio dan informasi keuangan yang dapat digunakan untuk memprediksi return perusahaan.

Beberapa faktor fundamental yang berasal dari perusahaan adalah rasio keuangan yang menjadi fokus perhaitan yang biasa digunakan untuk memprediksi return saham, dimana dari rasio keuangan yang dimaksud diantaranya adalah: (1) rasio likuiditas; (2) rasio aktivitas; (3) rasio profitabilitas; (4) rasio solvabilitas (leverage); dan (5) rasio pasar/ penilaian. Menurut Ulupui (2009) menyatakan rasio keuangan yang dapat mempengaruhi return saham, yang meliputi rasio likuiditas, rasio solvabilitas, rasio aktivitas, dan rasio profitabilitas. Dengan hasil bahwa hanya rasio aktivitas yang mempunyai pengaruh negatif dan rasio likuiditas, rasio solvabilitas, dan rasio profitabilitas berpengaruh positif terhadap return saham. Sedangkan penelitian Dyah (2007) juga membahas pengaruh kinerja keuangan terhadap return saham, yang meliputi rasio leverage dan rasio profitabilitas dan rasio pasar. Menyatakan hasil bahwa rasio leverage dan rasio profitabilitas mempunyai pengaruh yang negatif terhadap return saham, sedangkan rasio pasar berpengaruh positif terhadap return saham.

Indonesia merupakan negara yang memiliki sumber daya alam yang sangat melimpah, tidak hanya itu Indonesia juga terkenal dengan sebutan negara agraris karena sebagian besar mata pencaharian masyarakat Indonesia adalah bertani atau berkebun. Dengan banyaknya masyarakat yang bermata pencaharian bertani atau berkebun menyebabkan naiknya perekonomian masyarakat Indonesia sehingga diperkirakan hampir dari setengah perekonomian Indonesia disumbangkan dari kegiatan pertanian dan perkebunan. Didalam penelitian ini penulis menggunakan perusahaan perkebunan yang merupkan bagian dari sektor pertanian. Seperti diketahui perusahaan perkebunan beberapa tahun belakangan ini memiliki prospek investasi yang bagus dan lumayan menjanjikan. Kontribusi sektor perkebunan terhadap Perekonomian Indonesia cukup signifikan, terlihat dari porsi sektor perkebunan terhadap total PDB (Produk Domestik Bruto) pada tahun 
2011 dan 2012 masing-masing sebesar $14,7 \%$ dan $14,4 \%$ dimana angka tersebut adalah yang urutan ketiga terbesar setelah sektor pengolahan dan perdagangan, hotel dan restoran. Kondisi seperti inilah yang dapat dijadikan sebagai gambaran bagi para investor untuk berinvestasi di sektor perkebunan dan mendapat return sesuai dengan yang diharapkan.

Sebuah perusahaan mungkin saja mengalami return yang fluktuasi setiap tahunnya, hal ini dapat disebabkan oleh beberapa faktor baik itu mikro maupun makro serta internal dan eksternal. Hal ini pula yang dapat terjadi pada sektor perkebunan. Maka dari itu seorang investor harus menyadari bahwa disamping akan memperoleh keuntungan mereka juga akan mengalami kerugian. Keuntungan atau kerugian tersebut sangat dipengaruhi oleh kemapuan investor menganalisis keadaan harga saham. Untuk mengetahui itu maka diperlukanlah suatu analisis dengan menggunakan rasio keuangan menurut Desy (2012).

Berdasarkan permasalah di atas, Oleh karena itu peneliti tertarik untuk melakukan penelitian dengan menggunakan analisis rasio keuangan untuk mengetahui bagaimana pengaruhnya terhadap return saham pada perusahaan perkebunan yang terdaftar di Bursa Efek Indonesia selama periode 2010-2014. Dalam penelitian ini peneliti hanya menggunakan analisis rasio laporan keuangan yang dapat mengukur kinerja keuangan perusahaan dengan menggunakan Variabel Current Ratio (CR), Debt to Equity Ratio (DER), Total Assets Turnover (TAT), Return On Assets (ROA) dan Price Earning Ratio (PER) untuk melihat kondisi keuangan yang terjadi di perusahaan terhadap return saham. Penelitian ini akan menguji ulang serta mencari bukti empiris atas pengaruh analisa rasio keuangan terhadap return saham perusahaan perkebunan yang terdaftar di Bursa Efek Indonesia selama periode 2010-2014.

\section{REVIEW LITERATUR DAN HIPOTESIS}

\section{Landasan Teori}

1. Laporan Keuangan

Menurut Harahap (2007) laporan keuangan menggambarkan kondisi keuangan dan hasil suatu perusahaan pada saat tertentu atau jangka waktu tertentu.

\section{Kinerja Keuangan}

Kinerja keuangan merupakan instrumen analisa perusahaan yang ditujukan untuk menunjukan perubahan dalam kondisi keuangan perusahaan yang bersangkutan (Horne, 2012).

Dalam Penelitian ini pengukuran kinerja keuangan dapat dilihat dengan mengukur rasio Current Ratio, Debt to Equity Ratio, Total Assets Turnover, Return On Assets, Price Earning Ratio.

a. Current Ratio

Rasio yang paling umum digunakan untuk menganalisa posisi modal kerja suatu perusahaan (likuiditas) adalah dengan menggunakan current ratio (CR). Rasio ini menunjukkan perbandingan nilai kekayaan lancar (yang segera dapat dijadikan uang) dengan hutang jangka pendek (Munawir, 2004). Menurut Husnan (2002), current ratio adalah rasio yang mengukur sejauh mana kemampuan aktiva lancar perusahaan biasa dipergunakan untuk memenuhi kewajiban lancarnya.

\section{b. Debt to Equity Ratio}

Keputusan pendanaan berkaitan dengan sumber dana, baik yang berasal dari dalam (internal) maupun dari luar (eksternal). Penciptaan suatu struktur modal dapat mempengaruhi kebijakan dimana selanjutnya dapat mempengaruhi pengambilan keputusan strategis. Keputusan 
modal yang tepat sangat penting bagi perusahaan karena adanya kebutuhan untuk memaksimalkan keuntungan pada berbagai macam organisasi bisnis, keputusan tersebut juga berdampak pada suatu kemampuan perusahaan untuk dapat berjalan dengan lingkungan persaingannya (Restiyani, 2006). Debt to Equity Ratio selain digunakan untuk melihat struktur permodalan perusahaan juga bisa digunakan untuk melihat tingkat solvabilitas (penggunaan hutang) terhadap total shareholder's equity (Ang, 1997). DER yang tinggi menandakan modal usaha lebih banyak dibiayai oleh hutang dibandingkan dengan penggunaan modal sendiri.

Salah satu hal yang mempengaruhi tingkat return yang diperoleh oleh investor adalah financial risk. Tingkat financial risk menyatakan variabilitas laba yang akan diterima pemegang saham. Dan financial leverages adalah salah satu faktor yang mempengaruhi tingkat financial risk. Semakin banyak penggunaan financial leverages maka semakin banyak penggunaan biaya tetap (jangka panjang) yang dibutuhkan oleh perusahaan, sehingga laba operasional akan semakin kecil karena digunakan untuk menutup biaya jangka panjang dan beban bunganya. Hal ini menjelaskan bahwa semakin tinggi nilai rasio DER maka akan menyebabkan meningkatnya nilai hutang yang akan menyebabkan penurunan laba bersih yang pada akhirnya akan mengurangi laba yang diterima oleh pemegang saham (Sartono, 2001).

\section{c. Total Assets Turnover}

Total Asset

Turnover menunjukkan bagaimana efektifitas perusahaan menggunakan keseluruhan aktiva untuk meningkatkan nilai penjualan dan meningkatkan laba (Sartono, 2001)

TAT dipengaruhi oleh nilai penjualan bersih yang dilakukan oleh perusahaan dibandingkan dengan nilai aktiva total yang dimiliki oleh perusahaan. Bila nilai TAT ditingkatkan berarti terjadi kenaikan penjualan bersih perusahaan, peningkatan penjualan bersih perusahaan akan mendorong peningkatan laba yang akan direspon dengan peningkatan harga saham perusahaan yang pada akhirnya akan meningkatkan return saham perusahaan (Sartono, 2001).

d. Return On Assets

Return on Asset sering disebut juga sebagai Return on Investment (ROI). Rasio ini digunakan untuk mengukur seberapa efektif perusahaan memanfaatkan sumber ekonomi yang ada untuk menciptakan laba. ROA diperoleh dengan cara membandingkan nilai pendapatan bersih setelah pajak (Net Income After Tax / NIAT) terhadap rata-rata total aktiva/asset (average total asset). NIAT adalah nilai pendapatan / laba bersih setelah dikurangi dengan pajak. Average total asset adalah rata-rata jumlah asset dari awal tahun hingga akhir tahun. Semakin tinggi nilai ROA maka kinerja perusahaan semakin baik, karena tingkat pengembalian semakin besar (Ang, 1997).

Nilai ROA dipengaruhi oleh Net Income After Tax (pendapatan bersih sesudah pajak. Dengan meningkatnya ROA maka kemampuan perusahaan dalam meningkatkan kemampuan menghasilkan laba tinggi. Investor akan merasa aman dengan melakukan investasi pada perusahaan yang memiliki karakteristik seperti ini. 
e. Price Earning Ratio

Rasio ini digunakan untuk memprediksi kemampuan perusahaan dalam menghasilkan laba di masa yang akan datang. Kesediaan investor untuk menerima kenaikan PER sangat bergantung pada prospek perusahaan. Perusahaan dengan peluang tingkat pertumbuhan yang tinggi, biasanya memiliki PER yang tinggi. Sebaliknya perusahaan dengan tingkat pertumbuhan yang rendah cenderung memiliki PER yang rendah pula (Prastowo, 2005).

\section{Saham}

Saham dapat didefinisikan sebagai surat berharga sebagai bukti pernyataan atau pemilikan individu maupun institusi dalam suatu perusahaan (Bringham, 2006).

\section{Return Saham}

Return saham merupakan hasil yang diperoleh dari sebuah investasi. Return dapat berupa return realisasi (realized return) yaitu return yang telah terjadi atau return ekspektasi (Expected return) yaitu return yang diharapkan akan terjadi di masa yang akan datang (Jogiyanto, 2003).

\section{Penelitian Terdahulu}

Ulupui (2005) dalam penelitiannya tentang pengaruh rasio keuangan terhadap return saham pada perusahaan makanan dan minuman yang terdaftar di BEI. Variabel yang digunakan adalah CR, DER, TAT, dan ROA. Variabel CR dalam penelitian ini berpengaruh positif terhadap return saham.

Trisnaeni (2007) dalam penelitian yang berjudul pengaruh kinerja keuangan terhadap return saham perusahaan manufaktur yang terdaftar di BEJ. Variabel yang digunakan adalah EPS, PER, DER, ROI dan ROE. Variabel DER dalam penelitian ini berpengaruh negatif terhadap return saham.

\section{Hipotesis}

H1: Current Ratio berpengaruh positif terhadap return saham.

H2: Debt to Equity Ratio berpengaruh negatif terhadap return saham.

H3: Total Assets Turnover berpengaruh positif terhadap return saham.

H4: Return On Assets berpengaruh positif terhadap return saham.

H5: Price Earning Ratio berpengaruh positif terhadap return saham

\section{METODE PENELITIAN}

\section{Populasi dan Sampel}

Populasi penelitian merupakan jumlah keseluruhan dari subjek penelitian. Dalam penelitian ini populasi yang digunakan adalah semua perusahaan subsektor perkebunan yang listing di Bursa Efek Indonesia.

Metode dalam pemilihan sampel yang digunakan dalam penelitian ini adalah metode purposive sampling. Dengan tujuan untuk mendapatkan representatif sesuai dengan kriteria yang ditentukan. Adapun kriteria sampel yang akan digunakan yaitu :

1. Perusahaan perkebunan yang listing di Bursa Efek Indonesia periode 20102014

2. Ketersediaan dan kelengkapan data/ laporan keuangan selama periode 20102014 yang dibutuhkan dalam penelitian.

Berdasarkan data kualifikasi di atas maka ada 10 perusahaan yang bisa dijadikan sampel dalam penelitian ini.

\section{Definisi Operasional}

1. Variabel Independen

a. Current Ratio (CR)

Rasio CR digunakan untuk mengukur kemampuan aktiva lancar untuk menutupi kewajiban lancar (kewajiban jangka pendek) yang dimiliki perusahaan. Rasio CR mewakili rasio likuiditas dalam penelitian ini. CR didapatkan dengan 
cara membagi aktiva lancar dengan kewajiban lancar (kewajiban jangka pendek). Secara matematis CR dirumuskan sebagai berikut (Ang, 1997):

$$
\text { Current Ratio }=\frac{\text { AktivaLancar }}{\text { Hutang Lancar }}
$$

b. Debt to Equity Ratio (DER)

Rasio DER digunakan untuk mengukur seberapa efektif perusahaan memanfaatkan sumber ekonomi yang ada untuk menciptakan laba. Rasio DER mewakili rasio leverage atau rasio solvabilitas. DER didapatkan dengan membandingkan nilai total hutang dengan total modal sendiri. Secara matematis DER dituliskan dengan rumus berikut ini (Ang, 1997):

$$
\text { Debt to Equity Ratio }=\frac{\text { Total Debt }}{\text { Total Equitas }}
$$

\section{c. Total Asset Turnover (TAT)}

Rasio TAT digunakan untuk mengukur tingkatan efisiensi penggunaan seluruh aktiva untuk menghasilkan suatu tingkatan penjualan. Rasio TAT mewakili rasio aktivitas dalam penelitian ini. TAT didapatkan dengan membandingkan

penjualan/pendapatan netto dengan total aktiva. Secara matematis TAT dapat dituliskan dengan rumus sebagai berikut (Ang, 1997):

$$
\text { Total Assets Turnover }=\frac{\text { Penjualan }}{\text { Total Aktiva }}
$$

d. Return On Assets (ROA)

Rasio ROA digunakan untuk mengukur seberapa efektif perusahaan memanfaatkan sumber ekonomi yang ada untuk mendapatkan laba. Rasio ROA mewakili rasio profabilitas dalam penelitian ini. ROA didapatkan dengan cara membagi Earning After Tax (EAT) dengan total assets.
Secara matematis ROA dirumuskan sebagai berikut (Ang, 1997):

$$
\text { Return On Assets }=\frac{\text { EAT }}{\text { Total Aktiva }}
$$

e. Price Earning Ratio (PER)

Rasio PER digunakan untuk memprediksi kemampuan perusahaan dalam menghasilkan laba di masa yang akan datang. Rasio PER mewakili rasio nilai pasar dalam penelitian ini. PER didapatkan dengan cara membagi harga saham per lembar dengan EPS. Secara matematis PER dirumuskan sebagai berikut (Ang, 1997):

Price Earning Ratio $=\frac{\text { Harga Pasar Per Lembar }}{\text { EPS }}$

2. Variabel Dependen

Variabel dependen yang dijadikan objek dalam penelitian ini adalah return saham perusahaan perkebunan tahun 2010-2014.

Return merupakan hasil yang diperoleh dari suatu investasi. Return dapat berupa return realisasi yang terjadi atau return ekspektasi yang belum terjadi tetapi diharapkan akan terjadi di masa yang akan datang (Jogiyanto, 2000). Variabel return saham adalah variabel dependen pada penelitian ini. Disinyalir variabel return saham dipengaruhi oleh beberapa faktor lain secara matematis return saham dirumuskan sebagai berikut (Jogiyanto, 2000):

$$
\text { Actual Return }=\frac{(P t-P t-1)}{P t-1}
$$

Dimana :

$$
\begin{array}{ll}
\mathrm{P}_{\mathrm{t}} & =\text { Harga saham pada periode } \mathrm{ke}-\mathrm{t} \\
\mathrm{P}_{\mathrm{t}-1} & =\text { = Harga saham pada perode ke } \mathrm{t}-1
\end{array}
$$




\section{Uji Instrumen}

1. Uji Asumsi Klasik

a. Normalitas

Uji normalitas bertujuan untuk menguji apakah dalam sebuah model regresi, variable pengganggu atau residual mempunyai distribusi normal atau tidak (Ghozali, 2005). Jika terdapat normalitas, maka residual akan terdistribusi secara normal dan independen. Model yang paling baik adalah distribusi data normal atau mendekati normal.Uji ini dilakukan melalui analisis uji normalitas variabel residual. Apablila nilai Prob. J-B residual lebih besar dari a 5\% maka data distribusi normal.

b. Autokorelasi

Uji ini bertujuan untuk menguji apakah dalam sebuah model regresi linier ada korelasi antara kesalahan penganggu pada periode $t$ dan kesalahan pengganngu pada periode $\mathrm{t}-1$ (periode sebelumnya) (Ghozali, 2005:95). Model regresi yang baik adalah regresi yang bebas dari autokorelasi.Gejala autokorelasi dideteksi dengan menggunakan uji autokorelasi dengan eviews. Melakukan Uji Breusch-Godfrey, apabila nilai Prob. Chi-Square lebih besar dari a 5\% maka data tidak terkena autokorelasi.

c. Heteroskedastisitas

Uji ini bertujuan untuk menguji apakah dalam sebuah model regresi terjadi ketidaksamaan varians dari residual suatu pengamatan ke pengampatan yang lain (Ghozali, 2005:105). Jika varians dari residual suatu pengamatan ke pengamatan yang lain tetap, maka disebut homoskedastisitas. Jika varians tidak konstan atau berubah-ubah disebut dengan heteroskedastisitas.Model regresi yang baik adalah tidak terjadi heteroskedastisitas dalam penelitian ini menggunakan uji white dan uji BPG, apabila nilai Prob. Chi-Square pada $O b s^{*} R$-squared lebih besar dari a 5\% maka data tidak terkena heteroskedastisitas.

d. Multikolinieritas

Multikolinearitas digunakan untuk melihat apakah variabel independen yang satu dengan yang lain dalam model regresi tidak saling berhubungan secara sempurna dan mendekati sempurna. Untuk mengetahui ada tidaknya gejala multikolinearitas dapat dilihat dari besarnya nilai korelasi antar variabel independen dengan nilai korelasi yang rendah $(<70 \%)$.

\section{Teknik Analisis Data}

1. Analisis Deskriptif

Metode analisis deskriptif adalah metode analisis dimana data - data yang ada dikumpulkan, diklasifikasikan, dianalisis dan diinterpretasikan secara objektif sehingga memberikan informasi dan gambaran mengenai topic yang dibahas.

2. Analisis Regresi Berganda

Regeresi linier berganda dlikakukan untuk mengetahui pengaruh variabel bebas, yakni CR, DER, TAT, ROA, dan PER terhadap variabel terikat yaitu return saham perkebunan yang terdaftar di Bursa Efek Indonesia,

Dengan rumus :

$\mathrm{RS}=\mathrm{a}+\mathrm{b}_{1} \mathrm{CR}+\mathrm{b}_{2} \mathrm{DER}+\mathrm{b}_{3} \mathrm{TAT}+$ $\mathrm{b}_{4} \mathrm{ROA}+\mathrm{b}_{5} \mathrm{PER}$

Dimana :

$\begin{array}{lll}\text { RS } & = & \text { Return Saham } \\ \mathrm{a} & = & \text { Konstanta } \\ \mathrm{CR} & = & \text { Current Ratio } \\ \mathrm{DER} & = & \text { Debt to Equity Ratio } \\ \mathrm{TAT} & = & \text { Total Assets Turnover } \\ \mathrm{ROA} & = & \text { Return On Assets } \\ \mathrm{PER} & = & \text { Price Earning Ratio }\end{array}$




\section{Uji Hipotesis}

\section{Uji Parsial (Uji T)}

Digunakan untuk mengetahui apakah ada pengaruh signifikan atau tidak antara variabel independen dan variabel dependen secara individual atau parsial. Pengujian ini menggunakan uji $\mathrm{t}$ dengan tingkat keyakinan $95 \%$ atau signifikan $5 \%$ (alpha)

Kriteria pengujian berdasarkan nilai probabilitas (signifikansi) dasar pengambilan keputusan adalah:

a. Apabila nilai probabilitas < alpha, maka hipotesis diterima. Ini berarti bahwa variabel bebas secara parsial berpengaruh terhadap variabel terikat.

b. Apabila nilai probabilitas > alpha, maka hipotesis ditolak. Ini berarti bahwa variabel bebas secara parsial tidak berpengaruh terhadap variabel terikat.

\section{Uji Koefisien Determinasi}

Menurut Ghozali (2006) dan Hanani (2011), Koefisien determinasi $R^{2}$ diukur untuk mengetahui sejauh mana kemampuan model dalam menerangkan variabel dependen. Nilai koefisien determinasi yang biasanya diberi simbol $R^{2}$ menunjukkan hubungan pengaruh antara dua variabel yaitu variabel independen (CR, DER, TAT, ROA, dan PER) dan variabel dependen (return saham) dari hasil perhitungan tertentu.

Kelemahan mendasar penggunaan koefisien determinasi adalah bias terhadap jumlah variabel independen yang dimasukkan kedalam model. Setiap tambahan satu variabel independen, maka $R^{2}$ pasti meningkat tidak peduli apakah variabel tersebut berpengaruh secara signifikan terhadap variabel dependen. Oleh karena itu, banyak peneliti menganjurkan untuk menggunakan nilai adjusted $R^{2}$ pada saat mengevaluasi mana model regresi terbaik. Tidak seperti $R^{2}$, nilai adjusted $R^{2}$ dapat naik atau turunapabila satu variabel independen ditambahkan ke dalam model (Ghozali, 2006).

\section{HASIL PENELITIAN DAN PEMBAHASAN}

\section{Hasil Penelitian}

1. Hasil Uji Analisis Deskriptif

Statistik Deskriptif

\begin{tabular}{|l|c|c|c|c|c|c|}
\hline & RETURN & CR & DER & TAT & ROA & PER \\
\hline Mean & -0.060059 & 1.270140 & 1.068272 & 0.615428 & 0.075852 & 13.86152 \\
\hline Maximum & 0.606383 & 4.819256 & 3.198551 & 2.151639 & 0.250522 & 44.05000 \\
\hline Minimum & -0.824903 & 0.337349 & 0.163104 & 0.115262 & -0.142437 & -6.890000 \\
\hline Std. Dev. & 0.290789 & 0.840382 & 0.724832 & 0.474765 & 0.076909 & 9.406703 \\
\hline \multicolumn{6}{|c}{ Variabel Return mempunyai nilai }
\end{tabular}
minimum sebesar -0.824903 terdapat pada perusahaan LSIP (PP London Sumatera Indonesia Tbk), nilai maksimum sebesar 0.606383 pada perusahaan TBLA (Tunas Baru Lampung Tbk), dan nilai rata-rata sebesar -0.060059 dengan nilai standar deviasi sebesar 0.290789.

Variabel CR mempunyai nilai minimum sebesar 0.337349 terdapat pada perusahaan UNSP (Bakrie Sumatera Plantation Tbk), nilai maksimum sebesar 4.819256 pada perusahaan LSIP, dan nilai rata-rata sebesar 1.270140 dengan nilai standar deviasi sebesar 0.840382 .

Variabel DER mempunyai nilai minimum sebesar 0.163104 terdapat pada perusahaan LSIP, nilai maksimum sebesar 3.198551 pada perusahaan UNSP, dan nilai rata-rata sebesar 1.068272 dengan nilai standar deviasi sebesar 0.724832 .

Variabel TAT mempunyai nilai minimum sebesar 0.115262 terdapat pada perusahaan UNSP, nilai maksimum sebesar 2.151639 pada perusahaan SMAR (Sinar Mas Agro Resource and Technology Tbk), dan nilai rata-rata sebesar 0.615428 dengan nilai standar deviasi sebesar 0.474765 .

Variabel ROA mempunyai nilai minimum sebesar -0.142437 terdapat pada perusahaan UNSP, nilai 
maksimum sebesar 0.250522 pada perusahaan LSIP, dan nilai rata-rata sebesar 0.075852 dengan nilai standar deviasi 0.076909 .

Variabel PER mempunyai nilai minimum sebesar -6.890000 terdapat pada perusahaan GZCO (Gozco Plantation Tbk), nilai maksimum sebesar 44.05000 pada perusahaan BWPT (Eagle High Plantations Tbk), dan nilai rata-rata sebesar 13.86152 dengan nilai standar deviasi sebesar 9.406703 .

2. Hasil Uji Asumsi Klasik

a. Normalitas

Uji Normalitas

\begin{tabular}{|c|c|c|c|}
\hline Variabel & Metode Statistik & Prob. J-B & Kesimpulan \\
\hline Residual & Jarque-Bera & 0,606870 & Distribusi normal \\
\hline
\end{tabular}

Dari tabel di atas menunjukkan bahwa nilai Prob. J-B lebih besar dari $\alpha 5 \%(0,606870>0,05)$, maka variabel Return, CR, DER, TAT, ROA, PER berdistribusi normal.

b. Autokorelasi

\section{Uji Autokorelasi}

\begin{tabular}{|c|c|c|}
\hline Test & Prob. Chi-Square & Kesimpulan \\
\hline Breusch-Godfrey & 0.7895 & Tidak terkena autokorelasi \\
\hline
\end{tabular}

Berdasarkan hasil uji B-G di atas terlihat bahwa nilai prob. Chi Square sebesar 0.7895 yang mana lebih besar dari a 5\% (0.7895 > 0.05), sehingga kesimpulannya data tidak terkena masalah autokorelasi.

c. Heteroskedastisitas

Uji White dan Uji BPG

\begin{tabular}{|c|c|c|}
\hline Test & Prob. Chi-Square & Kesimpulan \\
\hline Breusch-Pagan-Godfrey & 0.0548 & $\begin{array}{c}\text { Tidak terkena } \\
\text { heteroskedastisitas }\end{array}$ \\
\hline White & 0.1302 & $\begin{array}{c}\text { Tidak terkena } \\
\text { heteroskedastisitas }\end{array}$ \\
\hline
\end{tabular}

Berdasarkan hasil uji white dan uji BPG diatas menunjukkan masing-masing nilai prob Chisquare pada Obs* R-squared lebih besar dari $0.05(\alpha)$. Jadi data tidak terkena masalah heteroskedastisitas. d. Multikolinieritas

Uji Korelasi Variabel Independen

\begin{tabular}{|c|c|c|c|c|c|c|}
\hline & RETURN & CR & DER & TAT & ROA & PER \\
\hline RETURN & 1 & -0.06897 & 0.07957 & 0.43394 & 0.25572 & 0.11555 \\
\hline CR & -0.06897 & 1 & -0.47199 & 0.30363 & 0.58135 & -0.17178 \\
\hline DER & 0.07957 & -0.47199 & 1 & -0.17116 & -0.66400 & -0.03919 \\
\hline TAT & 0.43394 & 0.30363 & -0.17116 & 1 & 0.52072 & -0.03727 \\
\hline ROA & 0.25572 & 0.58135 & -0.66400 & 0.52072 & 1 & 0.06088 \\
\hline PER & 0.11555 & -0.17178 & -0.03919 & -0.03727 & 0.06088 & 1 \\
\hline
\end{tabular}

Berdasarkan pada pengujian korelasi antar variabel di atas terlihat nilai korelasi yang rendah $(<70 \%)$ antar variabel independen. Jika variabel independen saling berkorelasi kurang dari 0,70 maka menunjukkan tidak adanya masalah multikolinearitas.

3. Hasil Uji Regresi Linier Berganda Hasil Uji Regresi Linier Berganda

\begin{tabular}{|c|c|c|}
\hline Variable & Coefficient & Std. Error \\
\hline C & -0.30882 & 0.16124 \\
\hline CR? & -0.13764 & 0.06222 \\
\hline DER? & 0.12273 & 0.07660 \\
\hline TAT? & 0.22440 & 0.11143 \\
\hline ROA? & 1.78583 & 0.86602 \\
\hline PER? & 0.00149 & 0.00420 \\
\hline
\end{tabular}

Berdasarakan hasil di atas maka model regresi pada data panel dapat dituliskann sebagai berikut:

$\mathrm{RS}=-0,30882-0,13764 \mathrm{CR}+$ $0,12273 \mathrm{DER}+0,22440 \mathrm{TAT}+$ 1,78583ROA + 0,00149PER

Dari persamaan regresi linier berganda di atas dapat diartikan sebagai berikut:

a. Nilai konstanta $=-0,30882$ yang artinya apabila tidak ada pengaruh variabel bebas (CR, DER, TAT, ROA, dan PER) maka besarnya Y $($ Return Saham $)=-0,30882$.

b. Koefisien regresi untuk variable Current Ratio( CR) sebesar -0,13764 yang bertanda negatif yang artinya jika CR naik satu rupiah maka return saham akan turun sebesar -0,13764 rupiah (dengan asumsi nilai koefisien variabel lain dalam model ini tetap atau tidak berubah). Namun sebaliknya, jika CR turun satu rupiah maka return saham akan naik 
sebesar -0,13764 rupiah (dengan asumsi nilai koefisien variabel lain dalam model ini tetap atau tidak berubah).

c. Koefisien regresi untuk variable Debt to Equity Ratio (DER) sebesar 0,12273 yang bertanda positif yang artinya jika DER naik satu rupiah maka return saham akan naik sebesar 0,12273 rupiah (dengan asumsi nilai koefisien variabel lain dalam model ini tetap atau tidak berubah). Namun sebaliknya, jika DER turun satu rupiah maka return saham akan turun sebesar 0,12273 rupiah (dengan asumsi nilai koefisien variabel lain dalam model ini tetap atau tidak berubah).

d. Koefisien regresi untuk variable Total Assets Turnover (TAT) sebesar 0,22440 yang bertanda positif yang artinya jika TAT naik satu rupiah maka return saham akan naik sebesar 0,22440 rupiah (dengan asumsi nilai koefisien variabel lain dalam model ini tetap atau tidak berubah). Namun sebaliknya, jika TAT turun satu rupiah maka return saham akan turun sebesar 0,22440 rupiah (dengan asumsi nilai koefisien variabel lain dalam model ini tetap atau tidak berubah).

e. Koefisien regresi untuk variable Return Assets Turnover (ROA) sebesar 1,78583 yang bertanda positif yang artinya jika ROA naik satu rupiah maka return saham akan naik sebesar 1,78583 rupiah (dengan asumsi nilai koefisien variabel lain dalam model ini tetap atau tidak berubah). Namun sebaliknya, jika ROA turun satu rupiah maka return saham akan turun sebesar 1,78583 rupiah (dengan asumsi nilai koefisien variabel lain dalam model ini tetap atau tidak berubah).

f. Koefisien regresi untuk variable Price Earning Ratio (PER) sebesar 0,00149 yang bertanda positif yang artinya jika PER naik satu rupiah maka return saham akan naik sebesar 0,00149 rupiah (dengan asumsi nilai koefisien variabel lain dalam model ini tetap atau tidak berubah). Namun sebaliknya, jika PER turun satu rupiah maka return saham akan turun sebesar 0.00149 rupiah (dengan asumsi nilai koefisien variabel lain dalam model ini tetap atau tidak berubah).

\section{Hasil Uji Parsial (Uji T) \\ Hasil Uji Regresi Linier Berganda}

\begin{tabular}{|c|c|c|c|c|}
\hline Variable & Coefficient & Std. Error & T-Statistic & Prob. \\
\hline C & -0.30882 & 0.16124 & -1.91523 & 0.062 \\
\hline CR? & -0.13764 & 0.06222 & -2.21207 & 0.032 \\
\hline DER? & 0.12273 & 0.07660 & 1.60216 & 0.116 \\
\hline TAT? & 0.22440 & 0.11143 & 2.01379 & 0.050 \\
\hline ROA? & 1.78583 & 0.86602 & 2.06209 & 0.045 \\
\hline PER? & 0.00149 & 0.00420 & 0.35528 & 0.724 \\
\hline R-Square & \multicolumn{4}{|c}{0.278878} \\
\hline
\end{tabular}

Dari tabel di atas diketahui Current Ratio (CR) memiliki nilai probabilitas signifikansi untuk variabel CR sebesar -0,032 lebih kecil dari taraf signifikansi 0,05 tetapi berpengaruh negatif. Maka hipotesis ditolak sehingga dapat disimpulkan bahwa secara parsial CR tidak berpengaruh terhadap return saham.

Dari tabel di atas diketahui Debt to Equity Ratio (DER) memiliki nilai probabilitas signifikansi untuk variabel DER sebesar 0,116 lebih besar dari taraf signifikansi 0,05 dan berpengaruh positif. Maka hipotesis ditolak sehingga dapat disimpulkan bahwa secara parsial DER tidak berpengaruh terhadap return saham.

Dari tabel di atas diketahui Total Assets Turnover (TAT) memiliki nilai probabilitas signifikansi untuk variabel TAT sebesar 0,050 lebih kecil dari taraf signifikansi 0,05 dan berpengaruh positif. Maka hipotesis diterima sehingga dapat disimpulkan bahwa secara parsial TAT berpengaruh positif terhadap return saham.

Dari tabel di atas diketahui Return

On Assets (ROA) memiliki nilai probabilitas signifikansi untuk variabel 
ROA sebesar 0,045 lebih kecil dari taraf signifikansi 0,05 dan berpengaruh positif. Maka hipotesis diterima sehingga dapat disimpulkan bahwa secara parsial ROA berpengaruh positif terhadap return saham.

Dari tabel di atas diketahui Price Earning Ratio (PER) memiliki nilai probabilitas signifikansi untuk variabel PER sebesar 0,724 lebih besar dari taraf signifikansi 0,05 dan berpengaruh positif. Maka hipotesis ditolak sehingga dapat disimpulkan bahwa secara parsial PER tidak berpengaruh terhadap return saham.

\section{Hasil Uji Koefisien Determinasi}

Uji Koefisien determinasi merupakan ukuran untuk mengetahui kesesuaian atau ketepatan hubungan variabel independen dengan variabel dependen dalam suatu persamaan regresi. Semakin besar nilai $\mathrm{R}^{2}$ atau $\mathrm{R}^{2}$ semakin mendekati satu maka semakin baik kemampuanvariabel $\mathrm{X}$ yang merupakan variabel bebas dapat menjelaskan variabel $\mathrm{Y}$ merupakan variabel terikatnya.

Koefisien determinasi atau $\mathrm{R}^{2}$ sebesar $0.278878 \quad(28 \%)$, artinya kemampuan varibel CR, DER, TAT, ROA dan PER dalam menjelaskan perubahan variabel return saham sebesar $28 \%$ sisianya diterangkan oleh variabel lain selain CR, DER, TAT, ROA dan PER sebesar $72 \%$.

\section{Pembahasan}

a. Analisis pengaruh current ratio (CR) terhadap return saham.

Hasil penelitian menunjukan hipotesi ditolak bahwa CR berpengaruh negatif terhadap return saham.Hal ini tidak konsisten dengan penelitian sebelumnya oleh Ulupui (2005) yang menyatakan bahwa secara parsial CR berpengaruh positif terhadap return saham. CR mempunyai berpengaruh negatif terhadap return saham hal ini bisa dipahami jika $\mathrm{CR}$ terlalu tinggi menunjukkan kurang baik, karena hal tersebut menunjukkan banyak aset perusahaan yang menganggur (aktivitas sedikit) dan yang pada akhirnya dapat mengurangi kemampuan laba perusahaan. Laba yang turun bisa mempengaruhi return saham berkurang sehingga berpengaruh negatif. Hasil ini sesuai dengan penelitian Machfoedz (1994) dimana CR berpengaruh negatif terhadap return saham.

b. Analisis pengaruhdebt to equity ratio (DER) terhadap return saham.

Hasil penelitian menunjukkan hipotesis ditolak bahwa variabel DER mempunyai pengaruh yang positif tetapi tidak berpengaruh terhadap return saham.Hal ini tidak konsisten dengan penelitian sebelumnya oleh Trisnaeni (2007) yang menyatakan bahwa secara parsial DER berpengaruh negatif terhadap return saham. Tidak adanya pengaruh DER terhadap return saham dikarenakan banyak perusahaan yang mempunyai hutang lebih besar dari modal ini menandakan bahwa tingginya resiko perusahaan untuk mengembalikan hutang, sehingga perusahaan akan mengalami kebangkrutan. Tinggi resiko perusahaan akan mengurangi minat investor untuk berinvestasi pada saham perusahaan yang memiliki hutang tinggi, sehingga tidak berpengaruh terhadap return saham. Hasil penelitian ini sesuai dengan penelitian yang dilakukan oleh Farkhan (2012) yang menyatakan bahwa DER tidak berpengaruh terhadap return saham.

c. Analisis pengaruh total assets turnover (TAT) terhadap return saham.

Hasil penelitian menunjukan hipotesis diterima bahwa TAT berpengaruh positif terhadap return saham. Peningkatan pada nilai TAT akan menyebabkan meningkatnya penjualan netto (penjualan bersih) yang dicapai perusahaan yang akan mendorong terjadinya peningkatan laba. Peningkatan laba akan mendorong 
terjadinya peningkatan return saham dengan kata lain peningkatan nilai TAT akan menyebabkan peningkatan return saham. Hasil penelitian ini bahwa TAT berpengaruh terhadap return saham didukung oleh penelitian yang dilakukan Restiyani (2006).

d. Analisis pengaruh return on assets (ROA) terhadap return saham.

Hasil penelitian menunjukkan hipotesi diterima bahwa ROA mempunyai pengaruh positif terhadap return saham. Meningkatnya ROA berarti di sisi lain juga meningkatkan nilai pendapatan bersih yang berarti meningkatkan nilai penjualan. Perusahaan yang penjualannya meningkat akan mendorong terjadinya peningkatan laba yang menunjukkan operasional perusahaan sehat dan baik. Hal ini akan disukai oleh para investor. Investor yang rasional tentu saja akan memilih investasi pada perusahaan yang memiliki profitabilitas tinggi, sehingga akan mendorong peningkatan harga saham yang pada akhirnya akan mendorong peningkatan return saham yang akan diterima investor. Hasil penelitian ini didukung oleh penelitian yang dilakukan oleh Ardhiastari (2006).

e. Analisis pengaruh price earning ratio (PER) terhadap return saham.

Hasil penelitian menunjukkan hipotesis ditolak bahwa variabel PER mempunyai pengaruh yang positif tetapi tidak berpengaruh terhadap return saham. Hal ini tidak konsisten dengan penelitian sebelumnya oleh Prasetyo (2005) yang menyatakan bahwa secara parsial PER berpengaruh positif terhadap return saham. Rasio ini mengukur kemampuan perusahaan untuk mencapai nilai di masyarakat, terutama pada pemegang saham dan calon investor.PER tidak mempengaruhi return saham dikarenakan adanya faktor lain seperti tindakan profit taking (ambil untung) yang dilakukan investor ketika saham mengalami kenaikan atau penurunan karena tidak stabilnya harga saham dan naik turunnya net income perusahaan. Hal ini didukung penelitian Munte (2009), Septi (2012) yang menyatakan bahwa PER tidak berpengaruh terhadap return saham.

\section{KESIMPULAN DAN SARAN}

\section{Kesimpulan}

1. Current Ratio (CR) tidak berpengaruh terhadap return saham pada perusahaan perkebunan.

2. Debt to Equity Ratio (DER) tidak berpengaruh terhadap return saham pada perusahaan perkebunan.

3. Total Assets Turnover (TAT) berpengaruh positif terhadap return saham pada perusahaan perkebunan.

4. Return On Assets (ROA) berpengaruh positif terhadap return saham pada perusahaan perkebunan.

5. Price Earning Ratio (PER) tidak berpengaruh terhadap return saham pada perusahaan perkebunan.

\section{Saran}

1. Populasi akan lebih baik kalau melibatkan seluruh perusahaan yang ada pada sektor pertaniaan.

2. Waktu penelitian menggunakan periode tahun terbaru supaya dapat menyesuaikan kondisi yang sedang terjadi.

3. Variabel penelitian dari masing-masing rasio keuangan harus diwakili lebih dari satu variabel.

4. Bagi para investor dan pihak lainnya diharapkan untuk tidak menjadikan analisis kinerja keuangan sebagai faktor utama dalam keputusan berinvestasi di pasar modal, namun juga harus memperhatikan kondisi-kondisi di luar perusahaan yang kemungkinan mempunyai pengaruh besar terhadap return saham.

5. Untuk para peneliti yang ingin mengembangkan penelitian ini lebih lanjut diharapkan untuk lebih banyak 
menambahkan variabel rasio keuangan lainnya, menambahkan periode waktu penelitian, dan memperbanyak populasi penelitian perusahaan sektor pertanian.

\section{DAFTAR PUSTAKA}

Ang, Robert. (1997). Buku Pintar Pasar Modal IndonesiaI. Jakarta: Media Staff.

Brigham, Eugene F dan Houston, Joel F. (2006). Dasar-Dasar Manajemen Keuangan. Edisi Kesepuluh. Jakarta: Salemba Empat.

Ghozali, Imam. (2005). Aplikasi Analisis Multivariate dengan Program SPSS. Semarang: Badan Penerbit Universitas Diponegoro.

Ghozali, Imam. (2006). Aplikasi Analisis Multivariate dengan Program SPSS. Edisi Keempat. Semarang: Badan Penerbit Universitas Diponegoro.

Harahap, Sofyan Syafri. (2007). Analisis Kritis Atas Laporan Keuangan. Jakarta: PT Raja Grafindo Persada.

Horne, James C. Van dan John M. Wachowicz, Jr. (2012). PrinsipPrinsip Manajemen Keuangan. Edisi Ketigabelas. Jakarta: Salemba Empat.

Husnan, Suad. (2002). Manajemen Keuangan Teori Dan Praktek. Yogyakarta: Yayasan Badan Penerbit Gajah Mada Yogyakarta.

Jogiyanto. (2000). Teori Portofolio dan Analisis Investasi. Yogyakarta: BPFE UGM.

Jogiyanto. (2003). Teori Portofolio dan Analisis Investasi. Edisi Kelima. Yogyakarta: BPFE UGM.

Munawir. (2004). Analisis Laporan Keuangan. Edisi Pertama Cetakan Ketiga. Yogyakarta: Ekonisia.

Sartono, Agus. (2001). Manajemen Keuangan Teori dan Aplikasi. Yogyakarta: BPFE Yogyakarta. 